\title{
An evaluative audit of the introduction of a new nursing document within a specialist palliative care inpatient unit in Ireland
}

\author{
Owen Doody $^{1 *}$, Maria E Bailey ${ }^{1}$, Sue Moran ${ }^{2}$ and Ann Marie Creaven ${ }^{3}$ \\ ${ }^{1}$ Department of Nursing and Midwifery, North Bank Campus, University of Limerick, Limerick, Ireland \\ ${ }^{2}$ Milford Care Centre, Castletroy, Limerick, Ireland \\ ${ }^{3}$ Department of Psychology, University of Limerick, Ireland
}

\begin{abstract}
Aim and objectives: To audit the introduction of a new nursing document within a specialist palliative care inpatient unit in Ireland.

Background: Nursing documentation contributes to effective patient care and communication between healthcare professionals and patients through providing a clear picture of; a patient's status, nurse's actions and care outcomes. However, documentation is often seen as a low priority and often lacks explicit information on
\end{abstract} patients'; preferences, needs and quality of life.

Design: An evaluative audit.

Results: Higher rates of documentation were evident in the unit using the new structured nursing documentation and significant differences were evident. Greater evidence of assessment, intervention and evaluation were evident in the new document and enabled nursing care to be evident and identifiable.

Conclusion: This project evaluated a new palliative nursing documentation system and identified that utilizing a structured document promoted accurate recording of clinical information and limits inconsistent documentation.

Relevance to clinical practice: An effective system for documentation improves the identification of quality care provided and facilitates individualized care.

\section{Introduction}

Palliative care is described as the total care of patients in order to achieve the best possible quality of life for patients and their families, encompassing care of body, mind, and spirit [1]. Inherent within safe, ethical and effective nursing practice is clear accurate and comprehensive documentation [2,3]. Documentation provides a clear picture of; the status of the patient, the actions of the nurse and care outcomes [4]. However, while nurses recognise documentation as important it is viewed as a low priority as nurses' first priority is to focus on patient care with documentation a lower priority [5]. Nonetheless healthcare systems are required to manage information to ensure continuity of care and effective information flow and nursing documentation contributes to effective patient care and communication between healthcare professionals and patients [6-8]. Engaging in good standards of record keeping is linked to improving quality patient care and as a means of protecting and safeguarding professional accountability, through facilitating effective communication between professionals as part of the multidisciplinary care of the person $[9,10]$. Quality documentation detailing patients' issues, nurses' actions or interventions and patient outcomes is an essential component of professional practice demonstrating high standards of care, where all members of the health care team can be informed of a patient's status and care [11-15].

Ensuring people are treated with dignity and respect is a core principle of end-of-life care and nurses working in various setting have an important role in supporting people at end-of-life $[16,17]$. In addition, nurses have a professional responsibility to work in partnership with others to provide person-centred compassionate care during the end-of-life period and nursing documentation supports this process [18]. However, there is always a need for improvement and the standards we aspire to and with this in mind patient outcome measures are considered as the way forward in clinical practice and have resulted in the use of more formal assessment tools in practice [16]. However, documentation often lacks explicit information on patients'; preferences, needs and quality of life and where nursing documentation identifies patients' preferences generally their voice is largely absent $[7,19]$. This article focusses on an evaluative audit of the introduction of a new nursing document within a specialist palliative care inpatient unit in Ireland which builds on an integrative review and the development of a new palliative care nursing document and audit tool $[20,21]$.

\section{Methods}

A health record audit examining nursing documentation and text from notes of 40 patient charts. Nursing documentation tools often focus on physical aspects of care, while this audit tool also focuses on psychological and spiritual aspects of care. The audit tool was developed

${ }^{\star}$ Correspondence to: Owen Doody, Department of Nursing and Midwifery, North Bank Campus, University of Limerick, Limerick, Ireland, Tel: 35321 31667, E-mail: owen.doody@ul.ie.

Key words: palliative care, audit, nursing documentation, inpatient, Ireland

Received: December 05, 2018; Accepted: December 28, 2018; Published: December 31, 2018 
and piloted and divided into three main sections [21]. The first was a number of clinical assessment tools which consisted of patient daily status, patients description of their day, symptoms assessment scales which is a patient rated scale that describes the patients level of stress relating to the patients physical symptoms and the palliative care problem severity score which is a clinician score to assess the overall degree of problems with the four key palliative domains which are; pain, other symptoms, psychological/spiritual and family/carer. The second was the essential elements of nursing care which are based on the Roper, Logan and Tierney activities of daily living consists of for example; pressure areas, mouth care, bed bathing, eating and drinking (i.e. mainly nursing tasks). The third was care bundles which can be described as a collection of interventions usually no more than five that can be applied to the management of a typical condition i.e. peripheral vascular catheter, subcutaneous lines and urinary catheters.

Ethical approval was obtained from the Health and Research Ethics Committees covering the care facility participating in the study. A pilot study had been carried out prior to the main study and one of the authors collected the data. Data were placed on a hard copy form of the survey and later entered into SPSS with response categories ranging from documented, not documented and not applicable. The assessors responsible for administering the audit had considerable experience with audit procedures and an experienced palliative care nurse. The selection criteria for inclusion in the study stipulated that all wards should (a) have implemented primary nursing for at least one year and (b) cater for an in-patient population. The audit was carried out in two wards in a Mid-West of Ireland specialist palliative care centre where charts from both Side A and Side B were monitored. Side A utilized the new nursing document and Side B utilized the existing nursing document [21]. Five charts were randomly taken from each side in June, August, October and December 2017, a total of 40 charts were randomly selected and audited in the six-month period. The ease and immediacy of obtaining reports made feedback by the assessors simple and timely and encouraged early completion of the quality cycle. QUASAR also provided a useful summary of data collected, detailing the number and percentage achieved.

\section{Results}

The findings from the audit reveal significant differences between Side A and B (Table 1). With regards to patient's daily status, Side A documented $100 \%$ of the time in the AM shift but only $60 \%$ of the time on the night shift. While Side B documentation on patient status was

Table 1. Audit finding Side A and Side B

\begin{tabular}{|c|c|c|}
\hline Scale & Side A & Side B \\
\hline Patient assessment scale & $100 \%$ & $85 \%, 15 \%$ not documented \\
\hline \multirow[t]{3}{*}{ Palliative care problem severity score } & $\begin{array}{l}80 \% \text { pain assessments documented, } 15 \% \text { not documented and } 5 \% \text { not } \\
\text { applicable }\end{array}$ & $95 \%$ pain assessments not documented, $5 \%$ not applicable, \\
\hline & $\begin{array}{l}70 \% \text { had documented nursing intervention, } 15 \% \text { not documented and } \\
15 \% \text { not applicable }\end{array}$ & $\begin{array}{l}90 \% \text { had nursing interventions documented, } 5 \% \text { not documented and } \\
5 \% \text { not applicable }\end{array}$ \\
\hline & $\begin{array}{l}65 \% \text { had documented nursing evaluation, } 15 \% \text { not documented and } \\
20 \% \text { not applicable }\end{array}$ & $\begin{array}{l}90 \% \text { had documented nursing evaluation, } 5 \% \text { not documented and } 5 \% \\
\text { not applicable }\end{array}$ \\
\hline \multirow[t]{3}{*}{ Other symptoms } & $80 \%$ of other symptoms documented, $20 \%$ not documented & $\begin{array}{l}0 \% \text { of other symptoms documented, } 85 \% \text { not documented, } 15 \% \text { not } \\
\text { applicable }\end{array}$ \\
\hline & $\begin{array}{l}70 \% \text { had documented nursing intervention, } 10 \% \text { not documented and } \\
20 \% \text { not applicable }\end{array}$ & $\begin{array}{l}55 \% \text { had nursing interventions documented, } 10 \% \text { not documented and } \\
35 \% \text { not applicable }\end{array}$ \\
\hline & $\begin{array}{l}65 \% \text { had documented nursing evaluation, } 15 \% \text { not documented and } \\
20 \% \text { not applicable }\end{array}$ & $\begin{array}{l}55 \% \text { had documented nursing evaluation, } 10 \% \text { not documented and } \\
35 \% \text { not applicable }\end{array}$ \\
\hline \multirow[t]{3}{*}{ Psychological issues } & $100 \%$ of patient's psychological issues assessed & $0 \%$ of patient's psychological issues assessed \\
\hline & $\begin{array}{l}55 \% \text { had documented nursing interventions, } 30 \% \text { had not documented } \\
\text { nursing interventions and } 15 \% \text { were not applicable }\end{array}$ & $\begin{array}{l}60 \% \text { had documented nursing interventions, } 5 \% \text { no documented nursing } \\
\text { interventions and } 35 \% \text { not applicable }\end{array}$ \\
\hline & $\begin{array}{l}55 \% \text { had documented nursing evaluation, } 30 \% \text { had not documented } \\
\text { nursing evaluation and } 15 \% \text { not applicable }\end{array}$ & $\begin{array}{l}30 \% \text { nursing evaluations documented, } 35 \% \text { not documented of nursing } \\
\text { evaluations, } 35 \% \text { not applicable. }\end{array}$ \\
\hline \multirow[t]{3}{*}{ Spiritual issues } & $80 \%$ assessed, $15 \%$ not documented, $5 \%$ not applicable & $0 \%$ assessed documented, $55 \%$ not documented, $45 \%$ not applicable \\
\hline & $\begin{array}{l}35 \% \text { had documented nursing interventions, } 30 \% \text { had no documented } \\
\text { nursing interventions } 35 \% \text { not applicable }\end{array}$ & $\begin{array}{l}25 \% \text { of nursing interventions that were documented, } 30 \% \text { not } \\
\text { documented and } 45 \% \text { not applicable }\end{array}$ \\
\hline & $\begin{array}{l}35 \% \text { had documented nursing evaluations, } 30 \% \text { had not documented } \\
\text { nursing evaluations and } 35 \% \text { not applicable }\end{array}$ & $\begin{array}{l}15 \% \text { of nursing evaluations being documented, } 40 \% \text { of nursing } \\
\text { evaluations not being documented and } 45 \% \text { not applicable }\end{array}$ \\
\hline \multirow[t]{3}{*}{ Family concerns } & $95 \%$ assessed and documented, $5 \%$ not & $0 \%$ assessed, $95 \%$ not documented, $5 \%$ not applicable \\
\hline & $\begin{array}{l}60 \% \text { had a nursing intervention documented, } 20 \% \text { of nursing } \\
\text { interventions not documented and } 20 \% \text { not applicable documented }\end{array}$ & $\begin{array}{l}60 \% \text { had nursing interventions documented, } 35 \% \text { not documented and } \\
5 \% \text { not applicable }\end{array}$ \\
\hline & $\begin{array}{l}45 \% \text { had a nursing evaluation documented } 35 \% \text { had no nursing } \\
\text { evaluation documented } 20 \% \text { not applicable }\end{array}$ & $\begin{array}{l}10 \% \text { of nursing evaluations were documented, } 85 \% \text { not documented, } \\
5 \% \text { not applicable }\end{array}$ \\
\hline Discharge planning & $5 \%$ in progress, $10 \%$ not documented and $85 \%$ not applicable & $20 \%$ in progress, $25 \%$ not documented and $55 \%$ not applicable \\
\hline Patient and family education & $10 \%$ in progress, $10 \%$ not documented and $80 \%$ not applicable & $5 \%$ in progress, $55 \%$ not documented and $40 \%$ not applicable \\
\hline Care bundles urinary catheter & $40 \%$ documented, $5 \%$ not documented and $55 \%$ not applicable & $\begin{array}{l}25 \% \text { of catheters being documented, } 25 \% \text { not documented and } 50 \% \text { not } \\
\text { applicable }\end{array}$ \\
\hline Care bundles hand hygiene & $40 \%$ compliance & $0 \%$ compliance \\
\hline Catheter bag being emptied & $40 \%$ compliance & $0 \%$ compliance \\
\hline \multirow[t]{2}{*}{ Peripheral vascular catheters } & $\begin{array}{l}\text { PVC lines in situ } 40 \% \text { documented, } 5 \% \text { not documented and } 55 \% \text { not } \\
\text { applicable }\end{array}$ & $\begin{array}{l}\text { PVC lines in situ } 15 \% \text { documented, } 25 \% \text { not documented and } 60 \% \text { not } \\
\text { applicable }\end{array}$ \\
\hline & $\begin{array}{l}30 \% \text { of compliance with further completion of PVC lines, } 20 \% \text { of not } \\
\text { compliance and } 50 \% \text { not applicable }\end{array}$ & $40 \%$ of not compliance with the remainder of the bundle \\
\hline \multirow[t]{2}{*}{ Sub cut lines in situ } & $40 \%$ documented, $10 \%$ not documented, $45 \%$ not applicable & $15 \%$ documented, $45 \%$ not documented and $40 \%$ not applicable \\
\hline & $\begin{array}{l}25 \% \text { compliance with the remainder of the bundle and } 30 \% \text { not } \\
\text { compliance }\end{array}$ & $\begin{array}{l}0 \% \text { compliance documented with the remainder of the bundle, } 60 \% \text { not } \\
\text { documented and } 40 \% \text { not applicable }\end{array}$ \\
\hline
\end{tabular}


zero. Overall on the patient assessment scale, Side A scored $100 \%$ and Side B scored $85 \%$. On the essential elements of nursing care both Side A side and Side B scored well on some aspects of the essential elements of nursing care; hygiene (100\%), pressures areas being assessed (100\%), daily monitoring of fluid and diet intake (100\%). For pressure prevention strategy, Side A reported $80 \%$ pressure prevention strategy, for documentation while Side B 0\%. Bed rail in use, Side A 95\% with $65 \%$ indicating a rational for same, Side B $100 \%$ not documented. There were significant differences in items audited between Side A and Side $\mathrm{B}$, specifically, for each of the five categories, more items are listed as completed for Side A compared to Side B. Each of these is statistically significant (independent t-tests - ps <.001) (Supplementary file 1).

Chi-square tests indicate that there are differences between the daily nursing content audit tool between Side A and Side B on each of the three items assessed, with these items completed more frequently at Side A. The tests for patient reported symptoms indicate that there is a difference between Side A and Side B in the use of a patient assessment scale where it is used at Side A but not Side B. However, there are no reliable differences for the items about taking nursing action on symptoms and evaluating the nursing action. There is insufficient data to assess the pre-symptom and post-symptom items. For palliative care items, there are differences between Side A and Side B (Side A better at addressing these items). For the other palliative care items there is either no difference at all or no meaningful differences. The patient/ family education item was rarely endorsed for Side B, but wasn't applicable very often for Side A, which is why we can't say there are differences.

For several of these essential elements of nursing care items the rate was $100 \%$ across both Sides, so these items appear to be done regardless of Side/form. There were some differences, where patients at risk of falls were more likely to be reassessed at Side A, and the prevention strategies implemented at Side A. However, very few patients were at risk of falls at Side B, so this result needs to consider in light of that fact. Although the difference was "significant" it cannot specifically be attributed to the new form. It could be that when the numbers of patients at risk of falls are high, nurses are more attentive to checking falls-related issues for individual patients. The daily pressure prevention strategy (12-hourly) differed from Side A to Side B. It was never completed at Side B and usually completed at Side A. Similarly results occurred for use of bedrail, and unsurprisingly for a rationale for use of the bedrail. There were also differences in documentation of care for infection. Although fewer patients in Side A had an infection, the care was more likely to be documented than for Side B. Also, there were differences in documentation of medication management 2 out of 3 had it documented in Side A in contrast to 10 out of 11 did not have this documented in Side B.

For most of the items in care bundles, there was not enough variation in whether the item was checked or not (where applicable) to draw substantive conclusions, particularly for the catheter items. There were no differences in checking catheters between sides. However, for the other catheter/PV/SC line items it could be tentatively said that Side A performed better at identifying inflammation, pain, leakage, dressing, and hand hygiene. The average level for each of the five areas in both sides A and B is identified (Table 2).

\section{Discussion}

There is a continual need to appraise and improve nursing documentation in line with the WHO (2002) position statement [1]. In recognising this fact, the current project developed a nursing
Table 2. Average levels of each class of item for Side A and Side B

\begin{tabular}{|l|c|c|c|c|}
\hline \multicolumn{1}{|c|}{} & Side & $\mathrm{N}$ & Mean & Std. Deviation \\
\hline Daily Nursing Content & $\mathrm{A}$ & 20 & 2.5500 & 0.60481 \\
\cline { 2 - 5 } Audit Tool & $\mathrm{B}$ & 20 & 0.1000 & 0.30779 \\
\hline Patient Reported & $\mathrm{A}$ & 20 & 3.0000 & 0.00000 \\
\cline { 2 - 5 } Symptoms & $\mathrm{B}$ & 20 & 1.7000 & 0.73270 \\
\hline \multirow{2}{*}{ Palliative Care } & $\mathrm{A}$ & 20 & 10.0500 & 3.89973 \\
\hline \multirow{2}{*}{$\begin{array}{l}\text { Essential Elements of } \\
\text { Nursing Care }\end{array}$} & $\mathrm{B}$ & 20 & 5.1500 & 2.56032 \\
\hline \multirow{2}{*}{ Care Bundles } & $\mathrm{A}$ & 20 & 13.4000 & 1.39170 \\
\hline & $\mathrm{B}$ & 20 & 9.5000 & 0.88852 \\
\hline
\end{tabular}

documentation recognising the need for a more holistic, personcentred approach to nursing documentation. The finding of this study highlights that using the new more person centred, and process focused nursing documentation ensured that physical, psychological and spiritual needs are well documented. This is essential given that generally nursing documentation has focused predominately on physical needs [22]. The move to capture psychosocial and spiritual needs is important given the philosophy of palliative care, which focuses on the total care of the individual and their family and the management of symptoms to achieve the best possible quality of life [1]. Such documentation supports clear, accurate and complete documentation, which is essential to the delivery of quality health care [3]. This bio-psycho-social approach to nursing documentation enables us to provide evidence of supporting the person's physical, psychological, social, and spiritual support needs and provides an efficient means of communicating patient information within the multidisciplinary team [21].

This study found that having a structured approach to nursing documentation ensures a greater likelihood that nursing activities will be recorded, as often nurses perform the necessary direct nursing care and forget to document $[11,23,24]$. This has relevance in modern healthcare given that only $40 \%$ of nursing activities observed are recorded [23]. Utilising a more holistic nursing document that recognises the relationships between the palliative care nurse, patient and family can support a partnership approach and enhance the quality of care [25]. Both sides (A and B) scored highly for documentation of nursing tasks, which is consistent with existing literature demonstrating that nursing tasks are more likely to be documented than notes on patients' progress or their response to nursing care. This is evident in the documentation from side B, where there was a $90 \%$ compliance with documenting nursing interventions, but no evidence of patient assessment ( $0 \%$ documented). It can be argued that if an assessment is not completed, appropriate nursing intervention and evaluation cannot be provided. This demonstrates the importance of structured documentation in the provision of quality care, recording nurse actions and patient preferences (voice). The process was reinforced by the WHO documentation guidelines, which state that documentation should be clear, concise, complete, correct, consecutive, contemporary, confidential, person-centred, collaborative and comprehensive [26].

Overall the findings reveal that the new documentation used on Side A improved the documentation of nursing support and documentation was significantly improved by using a structured document. The incorporation of a number of clinical assessment tools facilitated consistent formal documentation of assessment, intervention and evaluation of care delivery. However, the new documentation could be seen as increasing the volume of paperwork, but this has to be balanced against the necessity to capture nursing care provided. Nursing practice 
requires high quality documentation to ensure continuity of care, professional accountability and promote the uptake of evidence-based practice and to support this process continuing education is essential [27-29].

\section{Conclusion}

Documentation is a foundation for quality care and professional practice, as it enables transparent and consistent approaches to the planning and delivery of care [30]. This project has facilitated the evaluation of a new palliative nursing documentation system. The findings support the view that a structured document promotes the accurate recording of clinical information and limits inconsistent documentation [4]. The positive results demonstrate a clear step toward patient-centred nursing, which includes the patient's perspective leading to the strengthened transfer of information across the multidisciplinary team and improved quality of care [12].

\section{Funding statement}

This research received no specific grant from any funding agency in the public, commercial, or not-for-profit sectors."

\section{Conflict of interest}

The authors declare no conflict of interest.

\section{Author contributions}

Study design: SM, MB, OD; data collection: SM, data analysis: AMC, SM, OD, and manuscript preparation: OD, MB, SM.

\section{Acknowledgment}

We would like to acknowledge all the staff of the care centre for support and engagement in this project. In addition, we would like to thank Diane Jefferies for her support in developing the nursing document and audit tool, and consultation on this project.

\section{References}

1. World Health Organisation (2002) National cancer control programmes policies and managerial guidelines. 2nd edition. World Health Organisation, Geneva.

2. Gunningberg L, Fogelberg-Dahm M, Ehrenberg A (2009) Improved quality and comprehensiveness in nursing documentation of pressure ulcers after implementing an electronic health record in hospital care. J Clin Nurs 18: 1557-1564.

3. Voyer P, McCusker J, Cole MG, Monette J, Champoux N, et al. (2014) Nursing documentation in long-term care settings: new empirical evidence demands changes be made. Clin Nurs Res 23: 442-461.

4. Potter PA, Perry AG, Astle B, Duggleby W (2014) Canadian fundamentals of nursing. 5th edition. Mosby, Toronto.

5. Clancy TR, Delaney CW, Morrison B, Gunn JK (2006) The benefits of standardized nursing languages in complex adaptive systems such as hospitals. $J$ Nurs Admin 36: 426-434.

6. D’Agostino F, Zega M, Rocco G, Luzzi L, Vellone E, et al. (2013) Impact of a nursing information system in clinical practice: a longitudinal study project. Ann Ig 25: 329-341.

7. Laitinen H, Kaunonen M, Astedt-Kurki P (2010) Patient-focused nursing documentation expressed by nurses. J Clin Nurs 19: 489-497.

8. Lindström I, Gaston-Johansson F, Danielson E (2006) Documentation of patients' participation in care at the end of life. Nurs Ethics 13: 394-403. [Crossref]
9. Prideaux A (2011) Issues in nursing documentation and record-keeping practice. $\mathrm{Br} \mathrm{J}$ Nurs 20: 1450-1454. [Crossref]

10. Saranto K, Kinnunen UM, Kivekäs E, Lappalainen AM, Liljamo P, et al. (2014) Impacts of structuring nursing records: a systematic review. Scand J Caring Sci 28: 629-647. [Crossref]

11. Blair W, Smith B (2012) Nursing documentation: frameworks and barriers. Contemp Nurse 41: 160-168.

12. Jefferies D, Johnson M, Griffiths R (2010) A meta-study of the essentials of quality nursing documentation. Int $J$ Nurs Pract 16: 112-124. [Crossref]

13. Wong FW (2009) Chart audit: strategies to improve quality of nursing documentation. J Nurses Staff Dev 25: E1-6. [Crossref]

14. Gebru K, Ahsberg E, Willman A (2007) Nursing and medical documentation on patients' cultural background. J Clin Nurs 16: 2056-2065. [Crossref]

15. Cassimjee R, Mbabazi P (2006) The quality of nursing documentation in a hospital in Rwanda. Afr J Nurs Midwifery 8: 31-42.

16. National End of Life Care Programme (2011) Capacity, care planning and advance care planning in life limiting illness: a guide for health and social care staff. National Health System - National End of Life Care Programme, Leicester.

17. Schädle-Deininger H (2014) Subjective glance in ethics and attitudes in psychiatric nursing. Psychiatr Prax 41: S11-15. [Crossref]

18. Nursing and Midwifery Council (2015) Professional standards of practice and behaviour for nurses, midwives and nursing associates. Nursing and Midwifery Council, London.

19. Wang N, Hailey D, Yu P (2011) Quality of nursing documentation and approaches to its evaluation: a mixed-method systematic review. $J$ Adv Nurs 67: 1858-1875. [Crossref]

20. Doody O, Bailey ME, Moran S, Stewart K (2018) Nursing documentation in palliative care: an integrative review. J Nurs 5: 3 .

21. Stewart K, Doody O, Bailey M, Moran S (2017) Improving the quality of nursing documentation in a palliative care setting: a quality improvement initiative. Int J Palliat Nurs 23: 577-585.

22. Høgsnes L, Danielson E, Norbergh KG, Melin-Johansson C (2016) Healthcare professionals' documentation in nursing homes when caring for patients with dementia in end of life - a retrospective records review. J Clin Nurs 25: 1663-1673.

23. De Marinis MG, Piredda M, Pascarella MC, Vincenzi B, Spiga F, et al. (2010) If it is not recorded, it has not been done consistency between nursing records and observed nursing care in an Italian hospital. J Clin Nurs 19: 1544-1552.

24. Nielsen G, Peschel L, Burgess A (2014) Essential documentation elements: quality tool for the emergency department nurse. Adv Emerg Nurs J 36: 199-205. [Crossref]

25. Sawatzky R, Porterfield P, Lee J, Dixon D, Lounsbury K, et al. (2016) Conceptual foundations of a palliative approach: a knowledge synthesis. BMC Palliat Care 15: 5. [Crossref]

26. World Health Organization (2007) Guidelines for medical record and clinical documentation. World Health Organization, Geneva.

27. Nakate G, Dahl D, Drake KB, Petrucka P (2015) Knowledge and Attitudes of Select Ugandan Nurses towards Documentation of Patient Care. African J Nurs Midwifery 2: 56-65.

28. Whitcomb JJ, Seawright J, Flehan A, Echols L (2013) A retrospective study evaluating responses time and survival from cardiopulmonary arrest: A creative inquiry project with undergraduate nursing students. DimensCrit Care Nurs 32: 50-53.

29. Jefferies D, Johnson M, Nicholls D (2012) Comparing written and oral approaches to clinical reporting in nursing. Contemp Nurse 42: 129-138. [Crossref]

30. Gunningberg L, Fogelberg-Dahm M, Ehrenberg A (2009) Improved quality and comprehensiveness in nursing documentation of pressure ulcers after implementing an electronic health record in hospital care. J Clin Nurs 18: 1557-1564.

Copyright: (C2018 Doody O. This is an open-access article distributed under the terms of the Creative Commons Attribution License, which permits unrestricted use, distribution, and reproduction in any medium, provided the original author and source are credited. 